COLCHICINE AND DMSO AS PROBES FOR STUDYING PROTEIN1618 URIA IN PASSIVE HEYMANN NEPHRITIS. Lawrence S. Milner, Danny Lotan, Paul R. Goodyer, Jack S.C. Fong, and Bernard S. Kaplan. MeGill University, The Montreal

Children's Hospital, Department of Nephrology, Montreal, Quebec. In previous studies, we have shown that DMSO reduces proteinuria in passive Heymann nephritis (PHN). We have now extended these studies to include the use of colchicine (C), a known inhibitor of microtubule function. In addition, colchicine alters the shape of glomerular epithelial cells. Rats were treated with saline (controls) or C $(0.05 \mathrm{mg} / \mathrm{kg} / \mathrm{d}$ i.p. $x 28$ days). Controls excreted $105 \pm 22$ and C-treated rats, $37 \pm 6 \mathrm{mg} / \mathrm{d}, \mathrm{p}<0.05$. Onset of treatment during the autologous phase did not reduce proteinuria. Concomittant treatment with indomethacin abolished the beneficial effect of C. Whereas low doses of DMSO alone, and $C$ alone reduced proteinuria, a combination of the same doses of C plus DMSO provided no added advantage over each alone. These studie demonstrate that $\mathrm{C}$ and DMSO can reduce proteinuria in PHN possibly via a common mechanism. We have thus identified two probes which may be useful in studying the pathogenesis of proteinuria in this model.
PHOSPHATE (Pi) UPTAKE IN FETAL LAMB (PL) RENAL

1621 BRUSH BORDER MEMBRANES (BBMV). LAwrence Rufer, Dept. of Pediatrics, $\frac{\text { E. Moore, }}{1} \frac{\text { Christine }}{\text { ichael }}$ Reese Hosp. $\frac{\text { Mooers, }}{\text { Med. Ctr.; }} \frac{\text { and }}{\text { Dept. of }} \frac{\text { Park. }}{\text { Biol. }}$ Sci., University of Illinois at Chicago Graduate School; Chicago.

We investigated $\mathrm{Pi}$ uptake (PiU) in $\mathrm{BBMV}$ in $9 \mathrm{FL}$ and 6 ewes (E) at 100-165 days' gestation. BBMV were prepared by differential centrifugation, and $\mathrm{PiU}$ was measured by Millipore filtration. PiU after $1 \mathrm{~h}$ incubation in extravesicular media (EM) with [sucrose] from $0.3-1.0$ osm varied inversely with [1/osm] $(\mathrm{r}-0.94, \mathrm{p}<.01)$, indicating $\mathrm{PiU}$ into osmotically active BBMV. Results, $\mathrm{x}, \stackrel{+}{+}, \mathrm{nMol} / \mathrm{mg}$ protein: $(a-p<.01$; b-p<.005; c-p $<.001)$

\begin{tabular}{|c|c|c|c|c|c|}
\hline \multirow{3}{*}{$1 \mathrm{Na}^{+}-\mathrm{G}$} & & $.25 \mathrm{~min}$ & Peak & $5 \mathrm{~min}$ & $1 \mathrm{~h}$ \\
\hline & $\overline{\mathrm{FL}}$ & $10.6^{+}-0.8^{0}$ & $16.0^{+}-1.5^{2}$ & $11.0^{+}-1.1^{2}$ & $9.5^{ \pm}-0.7^{\mathrm{a}}$ \\
\hline & $\mathrm{E}$ & $4.4^{+} 1.9$ & $9.1_{-1.1}^{+}$ & $5.9_{-0}^{+} 0.5$ & $5.9_{-0.5}^{+}$ \\
\hline \multirow[t]{2}{*}{$\mathrm{O}-\mathrm{Na}^{+}$} & FL & $8.5^{+}-1.3^{\mathrm{b}}$ & $12.3_{-}^{+} 0.5^{\mathrm{c}}$ & $7.9_{-1.1}^{+} \mathrm{c}$ & $6.5^{+}-0.3^{b}$ \\
\hline & E & $2.4_{-}^{+} 0.6$ & $3.4^{+}-0.3$ & $3.4_{-}^{+} 0.3$ & $3.4_{-0.3}^{+}$ \\
\hline \multirow[t]{2}{*}{${ }^{2} \mathrm{Na}^{+}-\mathrm{Dep}$} & FL & 2.1 & 3.7 & 3.0 & 3.0 \\
\hline & $E$ & 1.1 & 5.3 & 2.8 & 3.8 \\
\hline
\end{tabular}

1-Na $\mathrm{FL}, \mathrm{Na}^{+}-\mathrm{G} \mathrm{PiU}$ varied directly with $\mathrm{EM} \mathrm{pH}$ from $6.5-8.5(\mathrm{r}-.79, \mathrm{p}<.01)$
and was 1.6 -fold greater at $\mathrm{pH} 6.5$ than at $\mathrm{pH} 8.5$. $\mathrm{Na}^{+}-\mathrm{G}$ PiU at $15 \mathrm{~s}$ and was $1.6-$ fold greater at $\mathrm{pH} 6.5$ than at $\mathrm{pH} 8.5 . \mathrm{Na}^{+}-\mathrm{G}$ PiU at $15 \mathrm{~s}$
in FL remained linear with EM [substrate] $0.1-3.0 \mathrm{~m} \mathrm{Mol}(\mathrm{r}-.99, \mathrm{p}<.001)$; however, $0-\mathrm{Na}^{+} \mathrm{PiU}$ was saturated at $0.8 \mathrm{mMol}$ with an apparent $\mathrm{Km}$ of $0.39 \mathrm{mMol}$ and $V \max$ of $48.4 \mathrm{nMol} / 15 \mathrm{~s} \cdot \mathrm{mg}$ protein. The results suggest significant differences between mechanisms of renal Pi handling in FL compared to $\mathrm{E}$ with non- $\mathrm{Na}^{+}$-Dep active $\mathrm{PiU}$ also present in FL. This may explain in part low renal Pi excretion in early life.
1619 CHEMOSENSORY FUNCTION IN CHILDREN WITH RENAL FAILURE.

1619 Merle Shapera, Dona1d Moe1, Gary Beauchamp, Richard Northwestern Univ., Children's Mem. Hosp., Dept. of Peds., Chicago. Several studies performed in both adults and children with either chronic renal insuf ficiency (CRI) or end-stage renal disease (ESRD) receiving dialyt ic support have shown that these patients have abnor-
mal taste acuity. Most of these abnormalities have been based on simple measurement of detection thresholds. The present studies example measurement of detection thresholds. The present studies exam-
ined taste and smell function in 10 CRI patients (mean creatinine 5.1 $\mathrm{mg} / \mathrm{d} 1$ ), mean age 13.7 years; 9 ESRD patients, mean age 14.3 years; and 9 control subjects with chronic illness (C) (hospitalized child psychiatry patients) mean age 11.0 years. Two parameters of taste function were determined: 1) Intensity test ing (IT) - perceived growth of intensity with increase in concentration; 2) Hedonic testing (HT) relationship between concentration and perceived pleasantness. Fo IT and $\mathrm{HT}$ all subjects were given 5 concentrat ions each of $\mathrm{NaCl}$ (N), sucrose (S) and quinine hydrochloride (Q) in the suprathreshold range. The scaling technique utilized for IT was magnitude estimation with a tape measure and for $\mathrm{HT}$ was "smiley-face" scale. Data were analyzed
by plott ing standard psychophysical functions. Smell function was by plotting standard psychophysical functions. Smell function was tested by UPSIT (Doty, RL: Univ. Of Penn. Sme11 Identification Test), ident ification of 40 microencapsulated odors in "scratch and sniff form. There were no dif ferences between the 3 groups in IT; the slope
of the 1 ine def ined by magnitude estimation of the 5 concentrations of $\mathrm{N}, \mathrm{S}$, and $\mathrm{Q}$ was similar in the 3 groups. All renal patients and $\mathrm{C}$ patients had similar preferences and dislikes for the 5 concentrations of $\mathrm{S}$ and $\mathrm{Q}$. However, renal patients had a substantially positive preference for higher concentrations of $\mathrm{N}$ compared to $\mathrm{C}$ patients. There were no significant differences between the 3 groups as to percent correct ressonses of the 40 odors in UPSIT. We conclude that patients with ESRD or CRI have normal IT, but seem to prefer $\mathrm{N}$ when
compared to C $\mathrm{Catient}$. Also, ability to identify common odors is
preserved in the two groups of renal patients.

\section{$\dagger 1620$}

PHOSPHATE (Pi) TRANSPORT IN RENAL BRUSH BORChristine S. Eddie $\frac{\text { S. Moore, Eunice }}{\text { G. }}$. John, Lawrence $\frac{\text { Rufer, }}{\text { Lochik Park, and }}$ Hosp. \& $\frac{\text { Med. }}{\text { Ctr., U. U. of Ill. }}$. College of Medicine, Dept. Pediatrics; U. of Ill. at Chicago Graduate Sch., Dept. Biological Sciences; Chicago. Renal $\mathrm{Pi}$ excretion (UPiV) is low in newborn infants and is not correlated with a low GFR. To further investigate UPiV in neonates, we measured $\mathrm{Pi}$ uptake ( $\mathrm{PiU}$ ) by Millipore filtration in BBMV in $7 \mathrm{P}$ at 10 days of age and in 3 adult dogs (D). BBMV were prepared by differential centrifugation and transport after $1 \mathrm{~h}$ incubation in extravesicular media (EM) with [sucrose] from 0.3 to $1.0 \mathrm{osm}$ varied inversely with [1/osm] $(r=.95, p<.05)$ indicating PiU into osmotically active BBMV. Results, $x,{ }^{+}$SEM, nMol/mg protein: ( $\left.a-p<.01 ; b-p<.005 ; c-p<.001\right)$

\begin{tabular}{|c|c|c|c|c|c|}
\hline \multirow{3}{*}{\multicolumn{2}{|c|}{$\begin{array}{ll} & \\
\mathrm{Na}^{+}-\mathrm{G} & \mathrm{P}\end{array}$}} & 1 minute & 2 minutes & 3 minutes & 1 hour \\
\hline & & $10.3 \pm 1.5$ & $11.5^{+} 1.3$ & $11.0^{+} 0.9$ & $9.8^{+} \pm 0.2$ \\
\hline & & $10.1 \pm 0.9$ & $16.2^{+}-0.7^{\mathrm{a}}$ & $16.7^{+}-0.7^{b}$ & $10.2_{-}^{+} 0.5$ \\
\hline $\mathrm{O}-\mathrm{Na}^{+}$ & P & $6.6^{+}-0.5^{2}$ & $6.9^{ \pm} \pm .5^{\mathrm{c}}$ & $7.4_{-0.3^{\mathrm{C}}}$ & 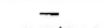 \\
\hline $2 \mathrm{Na}+\mathrm{Den}$ & D & $3.3^{ \pm}-0.5$ & $3.0 \pm 0.5$ & $3.9_{-}^{ \pm} 0.5$ & $5.3^{ \pm}-7.1$ \\
\hline${ }^{2} \mathrm{Na}^{+}-\mathrm{Dep}$ & $\begin{array}{l}\mathrm{P} \\
\mathrm{D}\end{array}$ & $\begin{array}{l}3.7 \\
6.8\end{array}$ & $\begin{array}{r}5.5 \\
13.1 \mathrm{c}\end{array}$ & $\begin{array}{r}3.6 \\
12.8^{\mathrm{c}}\end{array}$ & $\overline{4.6}$ \\
\hline
\end{tabular}

$1_{\mathrm{Na}^{+}}-$gradient $(\mathrm{G})\left(\left[\mathrm{Na}^{+}\right]_{\mathrm{O}}<\left[\mathrm{Na}^{+}\right]_{\mathrm{j}}\right)$ $13.1^{\mathrm{c}}$
INCREASED PERITONEAL PROTEIN LOSS IN PEDIATRIC PERITO-

1622 NEAL DIALYSIS. Bruce Z.Morgenstern, W. Keith Pyle, Alan Polinsky, H.Jorge Baluarte. St.Christopher's Hosp. for Childaren, Temple University School of Medicine, Philadelphia, PA.

Significant protein loss through the peritoneum of children on
Silation peritoneal dialysis(PD) has been well documented. To investigate this phenomenon, 8 children (mean age 10yrs, range 1-19) were studied. A single 8-hour isotope-labelled exchange was performed and timed dialysate samples were obtained. Data were analyzed by the model of Pyle. The model determines the diffusive and convective characteristics of the peritoneum:the mass transfer area coefficient (MTAC) and the reflection coefficient(RC). The MTAC is an area permeability product (ml/min) and the RC is the fraction of solute reflected at the membrane during the convection associated with ultrafiltration. The mean( \pm SD) MTAC and RC for urea were $17.7 \pm 7.9$ $\mathrm{ml} / \mathrm{min} / 1.73 \mathrm{~m}^{2}$ and $0.14 \pm 0.08$ respectively, for creatinine $11.6 \pm 7.0$ and $0.28 \pm 0.01$, for uric acid $7.7 \pm 3.9$ and $0.44 \pm 0.16$, for glucose $9.4 \pm 2.9$ and $0.49 \pm 0.17$, and for idealized total protein (T.P.) $0.12 \pm$ .15 and $0.95 \pm 0.03$. When compared with adult means, excepting T.P., these were not statistically significant. The MTAC for T.P. was larger than in adults $(\mathrm{p}<0.03)$, and the RC for T.P.was smaller than in adults $(p<0.01)$. This increased MTAC together with the lower RC signify that protein losses in children exceed those in adults. These data imply a greater large molecular weight solute removal in children on PD, resulting in effective clearance of uremic toxins. This may account for the low frequency of clinically manifest PD, despite relatively elevated serum Bun and creatinine tions. $\dagger 1623$ PREDICTIVE FACTORS AFFECTING FIRST PEDIATRIC CADAVERIC Baluarte, Eugene L.Sobel Bruce A Kaiser, Martin S. Polinsky, Sharon A.Perlman, Alan B.Gruskin. St.Christopher's Hosp. for Children. Dept. of Peds.,Temple Univ.Sch. of Med., Phila., PA. Transplantation remains the optimal replacement therapy for children with end stage renal disease. Cadaveric allograft survival (surv)has improved over the past decade. We reviewed our experience with 61 first cadaveric transplants performed from 1972 through 1982. Twenty-three recipients (388) were female and $38(628)$ were male; the mean ace was 11.2 yrs. (range 2-19). Forty-two (698) were white, $18(298)$ black, and $l(28)$ hispanic. Thirty-five $(57 \%)$ had received at least 5 random donor blood transfusions (trans). Thirty (508) were matched for a minimum of 2 HLA A and B antigens (Ag). (508) were matched for a minimum of 2 HLA $A$ and $B$ antigens (Ag)
Proportional hazards analysis (Cox's model) was used to examine 5 explanatory variables: sex, age, race, 25 trans, and number (no.) of $\mathrm{Ag}$ matches. Sex, aqe, and race did not affect graft surv. In this population, trans alone did not improve transplant $\operatorname{surv}(p>0.2)$. The no of Ag matches was positively correlated with graft surv. $(B=-0.3$, $\mathrm{p}<0.02)$. The combination of trans and Ag matching provided excellent allograft surv( 948 at $1 \mathrm{yr} .6785 \mathrm{yrs})$. This prompted an examination of the data including a variable termed AgTrans, a firstorder interaction of no. of Aq matches and trans status. AqTrans was the stroncest factor associated with prolonged surv. ( $B=-0.47$, $p<0.001)$. Use of the model predicts that at the time at which graft surv,would be $50 \%$ with $<5$ trans and no Ag matches, it would increase to $68 \%$ with a $2 \mathrm{Ag}$ match, and increase further to $85 \%$ with both a 2 Ag match and $\geq 5$ trans. In summary, Aq matchinc acts as an initiator in pediatric cadaveric transplantation and 25 trans act as a promotor of graft function.
$\mathrm{mMol}(\mathrm{r}=0.99, \mathrm{p}<.001)$; however, $0-\mathrm{Na}^{+} \mathrm{PiU}$ was saturated at $1.0-2.0$ $\mathrm{mMol}$ with an apparent $\mathrm{Km}$ of $0.84 \mathrm{mMol}$ and $\mathrm{Vmax}$ of $382.2 \mathrm{nMol} /$ $15 \cdot \mathrm{mg}$ protein. The results suggest that non- $\mathrm{Na}^{+}-\mathrm{Dep}$ active PiU may explain in part low UPiV in young infants. 